\title{
ANALISIS TERHADAP KETERBUKAAN INFORMASI PUBLIK PADA PERSEROAN TERBATAS YANG MELAKUKAN PENGUMPULAN DANA DONASI YANG DIDUGA DIGUNAKAN UNTUK PELAKSANAAN CORPORATE SOCIAL RESPONSIBILITY
}

\author{
Muhammad Rizqi \\ (Mahasiswa Program S1 Fakultas Hukum Universitas Tarumanagara) \\ (E-mail: muhamadrizqi.fh@gmail.com) \\ Dr. Chandra Yusuf, S.H., LLM., MBA., MMgt \\ (Corresponding Author) \\ (Dosen Fakultas Hukum Universitas Tarumanagara. Meraih Sarjana Hukum pada Fakultas Hukum \\ Universitas Indonesia, Magister Hukum pada Fakultas Hukum Universitas Melbourne Australia, \\ Doktor (Dr.) pada Fakultas Hukum Universitas Indonesia) \\ (E-mail: chandra.yusuf@gmail.com)
}

\begin{abstract}
Public Institution is a legal person under the Indonesian act number 14 year of 2008 about Public Information Openness. Under that act, Public Institution have an obligation to publish all the information on that regulation. Public Institution, under the Indonesian act of Public Information Openness means legislative, executive, judicative and any other institution who obtain operational funds from state income (ABPN) or regional income (APBD), public funds or foreign income. There's an issue among Private Company and Public Information Commission, where the Private Company appointed as a Public Institution by the Judge from Indonesian Information Public Commission. There's a gap on that dispute, because Private Company obeyed under the Indonesian act of Private Company number 40 year of 2007. The judge had consideration when decided Private Company to become a Public Institution, it's because of that Private Company managed public donation and distribute that donation into several foundation. The other problem is the private company refused to be named as a Public Institution, so there's no obligation for the private company to publish any information about the corporation.
\end{abstract}

Keywords: Public Institution, Private Company, Public Information.

\section{I.PENDAHULUAN}

\section{Latar Belakang}

Globalisasi dapat dikenal dengan proses mendunia, telah mempengaruhi kemajuan dalam berbagai aspek, salah satunya Indonesia. Kemajuan tersebut meliputi aspek-aspek ekonomi, sosial, budaya, tak terkecuali teknologi dan industri. Di tengah pusaran arus globalisasi atau yang dikenal dengan dunia tanpa batas, tekanan untuk 
Volume 2 Nomor 2, Desember 2019

E-ISSN : 2655-7347

melakukan hubungan dengan negara-negara lain kian menguat, hal ini tentunya tidak terlepas dari manusia sebagai makhluk sosial. Mengutip dari buku Soehino yakni Ilmu Negara Liberty, Plato berpendapat bahwa negara adalah suatu tubuh yang senantiasa maju, berevolusi dan terdiri dari orang-orang (individu-individu) yang timbul atau ada karena masing-masing dari orang itu secara sendiri-sendiri tidak mampu memenuhi kebutuhan dan keinginannya yang beraneka ragam, yang menyebabkan mereka harus bekerja sama untuk memenuhi kepentingan mereka bersama. ${ }^{1)}$ Dari pendapat Plato tersebut, dapat disebutkan bahwa suatu masyarkat yang hidup dalam suatu negara akan senantiasa berevolusi dan saling berhubungan demi memenuhi kebutuhannya masing-masing.

Agar menjamin tidak adanya konflik di dalam hubungan antar masyarakat di berbagai negara dalam memenuhi kebutuhannya, tentu diperlukan suatu koridor hukum yang membuat hubungan antar masyarakat era globalisasi tersebut tetap harmonis serta menjamin kepastian dan keadilan bagi seluruh masyarakatnya selaras dengan tujuan hukum. Hal tersebut serupa dengan pendapat Satjipto Rahardjo yang mengatakan bahwa secara teknis hukum merupakan suatu sarana untuk menjamin kepastian dan memberikan prediktibilitas di dalam kehidupan masyarakat. ${ }^{2)}$ Dalam kaitannya dengan globalisasi, maka kegiatan perekonomian pun juga melangkah maju, hal ini dibuktikan dengan kian menjamurnya berbagai macam kegiatan usaha yang ada di Indonesia. Salah satu cara yang umum dilakukan sebagai salah satu kegiatan usaha adalah membentuk suatu perusahaan.

Banyaknya berbagai jenis perusahaan, dapat dipersempit ke dalam berbagai aspek sehingga dapat mempermudah untuk mengenali suatu perusahaan. Dalam aspek kepemilikan modal perusahaan, terdapat 2 (dua) jenis perusahaan yang sebagian besar modalnya dimiliki oleh negara atau yang dikenal dengan istilah Badan Usaha Milik Negara (untuk selanjutnya disebut BUMN) dan perusahaan yang

${ }^{1)}$ Soehino, Ilmu Negara Liberty, (Yogyakarta: 1980), hal. 17

2) Satjipto Rahardjo, Hukum dalam Perspektif Sejarah dan Perubahan Sosial dalam Pembangunan Hukum dalam Perspektif Politik Hukum Nasional, (Jakarta: Rajawali Press, 1996), hal. 19. 
Volume 2 Nomor 2, Desember 2019

E-ISSN : 2655-7347

dimiliki oleh pihak swasta. Khusus mengenai perusahaan yang dimiliki oleh pihak swasta, terbagi lagi ke dalam beberapa jenis, yakni Persekutuan Perdata, Firma, CV, dan Perseroan Terbatas. Banyaknya berbagai macam perusahaan ataupun kegiatan usaha yang terdapat di Indonesia seperti yang telah disebutkan sebelumnya, tentu melahirkan kepentingan-kepentingan dari masing-masing pihak demi melangsungkan kegiatan usahanya tersebut, sehingga diperlukan aturan yang mengatur kegiataan usaha tersebut agar tetap menciptakan ekosistem perusahaan yang baik. Pemerintah dalam hal ini telah membuat suatu payung hukum demi melindungi berbagai macam perusahaan yang terdapat di Indonesia.

Kitab Undang-Undang Hukum Dagang (untuk selanjutnya disebut sebagai KUHD), merupakan langkah konkret pemerintah dalam menciptakan kegiatan usaha yang sesuai dengan koridor hukum. Khusus mengenai perseroan terbatas, pemerintah membuat undang-undang yang khusus mengatur mengenai badan usaha tersebut, yaitu Undang-Undang Negara Republik Indonesia Nomor 1 Tahun 1995 Tentang Perseoran Terbatas yang kemudian diubah menjadi Undang-Undang Negara Republik Indonesia Nomor 40 Tahun 2007 Tentang Perseroan Terbatas (untuk selanjutnya disebut UUPT).

Berdasarkan definisi perseroan terbatas yang terdapat di dalam UUPT, saham merupakan modal utama dalam perseroan terbatas. Dari sudut pandang ekonomi, terdapat beberapa sumber harta Perseroan Terbatas yang didapatkan dari Dana Pribadi maupun Dana Pinjaman dari berbagai lembaga keuangan. Selama dana tersebut diperoleh dengan cara yang sesuai dengan hukum, maka negara memberikan kebebasan dalam membentuk badan usaha yang sesuai dengan koridor hukum. Selain definsi, terdapat ketentuan lain untuk sebuah perseroan terbatas dalam menjalankan kegiatan usahanya, yaitu Tanggung Jawab Sosial dan Lingkungan (untuk selanjutnya disebut TJSL) atau dalam istilah lain Corporate Social Responsibility. Suatu perseoran terbatas diwajibkan untuk melakukan kegiatan tanggung jawab sosial dan lingkungan dengan tujuan memberikan dampak yang baik bagi masyarakat dan lingkungan disekitar perseroan. Selain UUPT, terdapat Peraturan Pemerintah Nomor 
Volume 2 Nomor 2, Desember 2019

E-ISSN : 2655-7347

47 Tahun 2012 Tentang Tanggung Jawab Sosial dan Lingkungan Perseroan Terbatas yang mengatur mengenai tanggung jawab sosial dan lingkungan.

Berdasarkan keseluruhan Undang-undang tersebut, dapat terlihat bahwa pemerintah tengah mengambil langkah konkret untuk melibatkan suatu badan usaha dalam melakukan pembangunan, pemeliharaan dan peningkatan taraf yang diperuntukan bagi masyarakat di sekitar lingkungan perusahaan. Selain kewajiban untuk menjalankan TJSL sebagaimana yang diatur dalam UUPT, keterbukaan informasi terkait dengan kegiatan usaha yang dijalankan oleh suatu badan hukum khususnya Perseroan Terbatas menjadi penting demi menjaga hubungan yang baik antar pemangku kepentingan baik yang terlibat langsung maupun tidak langsung di dalam Perseroan tersebut. Walaupun UUPT sejatinya tidak memberikan kewajiban untuk membuka seluruh informasi suatu Perseroan Terbatas, terdapat kewajiban lain untuk menyerahkan laporan keuangan Perseroan Terbatas kepada akuntan publik untukdi audit dan diumumkan di dalam satu surat kabar sebagaimana yang terdapat di dalam pasal 68 ayat (4) UUPT. Adapun penjelasan pasal tersebut menyebutkan pengumuman tersebut dalam rangka akuntabilitas dan keterbukaan kepada masyarakat, sehingga dalam hal ini keterbukaan informasi secara terbatas tersebut dimaksudkan untuk menjalakan prinsip Good Corporate Governance dan merupakan hak daripada pemangku kepentingan untuk mendapatkan keterbukaan informasi.

Walaupun secara jelas UUPT telah mengatur berbagai hal tentang Perseroan Terbatas mengenai ketentuan yang sifatnya umum hingga ketentuan yang bersifat administrasi berserta CSR, namun tampaknya masih terjadi kekosongan hukum dalam pelaksanaannya sehingga menimbulkan ketidakpastian hukum bagi para pelaku usaha dalam menjalankan usahanya, salah satunya adalah sengketa informasi publik antara Mustolih melawan PT Sumber Alfaria Trijaya.

PT. Sumber Alfaria Trijaya Tbk, merupakan sebuah badan hukum yang bergerak di bidang kegiatan perdagangan Supermarket/Hypermarket yang memperdagangkan barang-barang keperluan sehari-hari. Dilansir dari CNN indonesia, PT. Sumber Alfaria Trijaya Tbk, melakukan pengumpulan dana donasi yang bersumber dari uang 
Volume 2 Nomor 2, Desember 2019

E-ISSN : 2655-7347

kembalian masyarakat yang berbelanja di Alfamart yang merupakan toko retail milik PT. Sumber Alfaria Trijaya Tbk. Adapun pengumpulan dana donasi yang dikumpulkan oleh Alfamart, dilakukan dengan cara seorang petugas kasir menanyakan kesediaan dari konsumen yang berbelanja di Alfamart untuk menyumbangkan uang kembaliannya untuk didonasikan. Retang uang kembalian yang didonasikan adalah kisaran Rp100,00 (seratus rupiah) sampai dengan Rp400,00 (empat ratus rupiah).

Mustolih yang merupakan salah satu konsumen di Alfamart dan menyumbangkan uangnya tersebut, mempertanyakan kepada kasir mengenai penggunaan uang kembalian yang dikumpulkan oleh Alfamart tersebut. merasa tidak mendapat jawaban yang memuaskan, Mustolih melayangkan surat kepada direktur Alfamart. Isi surat tersebut adalah pertanyaan terkait surat izin meminta donasi dari masyarakat, proposal perizinan donasi, laporan keuangan yang teraudit, hingga pihak penerima dana tersebut. ${ }^{3)}$ Mustolih pun mendapat jawaban terkait dengan legalitas pengumpulan dana donasi dari PT. Sumber Alfaria Trijaya Tbk, yang menyatakan telah diatur oleh kementerian sosial, serta PT. Sumber Alfaria Trijaya Tbk, mengklaim telah mempublikasikan laporan donasi serta penyalurannya secara transparan kepada publik melalui berbagai media dan website perusahaan. Mustolih tidak puas terhadap jawaban dari PT. Sumber Alfaria Trijaya Tbk, sehingga kembali melayangkan surat kepada perusahaan tersebut, namun tidak mendapatkan jawaban.

Lebih lanjut, Komisi Informasi Pusat memutuskan agar jaringan toko Alfamart, PT. Sumber Alfaria Trijaya Tbk (SAT), memberikan informasi terbuka mengenai donasi yang diterima dari masyarakat. ${ }^{4)}$ Salah satu pertimbangan hukum putusan KIP adalah PT Sumber Alfaria Trijaya yang mengabungkan penggunaan dana donasi dengan laporan tanggung jawab sosial perusahaan (corporate social responsibility) dalam laporan tahunan perusahaan (annual report) 2015.5) Hal tersebut merupakan

\footnotetext{
${ }^{3)}$ Raja Eben Lumbanrau, "Putusan KIP: Alfamart Gunakan Donasi Untuk CSR Perusahaan”, (CNN Indonesia: 2016), www.cnnindonesia.com, diakses pada 6 februari 2019 pukul 01.34 WIB.

${ }^{4)}$ Ibid.

${ }^{5)}$ Ibid.
} 
Volume 2 Nomor 2, Desember 2019

E-ISSN : 2655-7347

awal buntut panjang dari salah seorang konsumen yang melaporkan gugatan tersebut kepada KIP, dimana seorang warga Tangerang Selatan Mustolih Siradj yang menjelaskan salah satu alasannya menggugat PT Sumber Alfaria Trijaya, karena perusahaan itu mengatasnamakan sumbangan donasi masyarakat itu sebagai tanggung jawab sosial perusahaan. Padahal, dana CSR, menurut Mustolih, seharusnya diambil dari keuntungan perusahaan. ${ }^{6}$

Dalam sengketa informasi ini, hakim menganggap bahwa PT Sumber Alfaria Trijaya, masuk ke dalam ranah badan publik sesuai dengan Undang-Undang Negara Republik Indonesia Nomor 14 Tahun 2008 Tentang Keterbukaan Informasi Publik (untuk selanjutnya disebut UU KIP). Dari pengertian pada pasal tersebut, menimbulkan suatu asumsi mengenai PT Sumber Alfaria Trijaya yang merupakan perseroan terbatas tunduk pada UUPT sehingga tentulah harus menjalankan publikasi terhadap informasi pengumpulan dana yang digunakan untuk keperluan CSR. Melihat kembali ketentuan UU KIP mengenai Badan Publik, dapat diketahui bahwa badan publik memliki tugas pokok beserta fungsi yang berbeda dengan Perseroan Terbatas, hal ini tentunya menjadi lampu kuning tersendiri bagi perusahaan-perusahaan swasta lain yang semata-mata menjalankan kewajiban CSR karena sewaktu-waktu dapat menimbulkan masalah. Kembali perlu ditegaskan bahwa suatu Perseroan Terbatas yang masuk ke dalam Ranah Badan Publik, tentu memiliki akibat hukum apabila tidak menyediakan informasi sesuai yang tercantum dan diwajibkan oleh UU KIP.

\section{Perumusan Masalah}

1. Apakah pelaksanaan Corporate Social Responsibility oleh suatu Perseroan Terbatas merupakan Informasi Publik yang tunduk pada ketentuan Undang-Undang NRI Nomor 14 Tahun 2008 Tentang Keterbukaan Informasi?

6) Ibid. 
Volume 2 Nomor 2, Desember 2019

E-ISSN : 2655-7347

2. Bagaimana akibat hukum terhadap suatu badan publik yang tidak menjalankan keterbukaan informasi sesuai dengan Undang-Undang NRI Nomor 14 Tahun 2008 Tentang Keterbukaan Informasi Publik?

\section{Metode Penelitian}

Untuk menemukan sebuah hasil dalam penelitian yang dilakukan yakni kebenaran baik kebenaran secara korespondensi, koherensi, pragmatis dan semantik seperti yang dikemukakan oleh Peter Mahmud Marzuki dalam bukunya. ${ }^{7}$ Menurut Soerjono Soekanto Penelitian adalah suatu kegiatan ilmiah yang ada kaitannya dengan analisa dan konstruksi yang dilakukan secara metodologis, sistematis, dan konsisten. Metodologi berarti sesuai dengan metode atau cara tertentu, sistematis berarti berdasarkan suatu sistem, sedangkan konsisten berarti tidak adanya hal-hal yang bertentangan di dalam suatu kerangka Suatu penelitian secara ilmiah dilakukan untuk menyalurkan hasrat ingin tahu yang telah mencapai taraf ilmiah, yang disertai suatu keyakinan bahwa setiap gejala akan ditelaah dan dicari hubungan sebab akibatnya atau kecenderungan-kecenderungan yang timbul. Lebih lanjut, Soerjono Soekanto mengatakan bahwa Penelitian merupakan sarana yang digunakan untuk memperkuat, membina serta mengembangkan ilmu pengetahuan. ${ }^{8)}$ Definisi lebih lanjut mengenai penelitian yang merupakan suatu usaha pencarian jawaban yang benar, sebuah kata istilah dalam bahasa Indonesia yang dipakai sebagai kata terjemahan apa yang di dalam Inggris disebut Research. ${ }^{9)}$

Penelitian hukum merupakan suatu kegiatan ilmiah yang didasarkan pada metode, sistematika dan pemikiran tertentu, yang bertujuan untuk mempelajari satu atau beberapa gejala hukum tertentu dengan jalan menganalisanya. Selain itu, juga diadakan pemeriksaan yang mendalam terhadap fakta hukum, untuk kemudian mengusahakan suatu pemecahan atas permasalahan-permasalahan yang timbul di

\footnotetext{
7) Peter Mahmud Marzuki, Penelitian Hukum: Edisi Revisi, (Surabaya: Kencana, 2005), hal.22.

8) Soerjono Soekanto, Pengantar Penelitian Hukum, (Jakarta: UI Press, 1986), hal. 3

9) Sulistyowati Irianto \& Shidarta, Metode Penelitian Hukum: Konstelasi dan Refleksi, (Jakarta: Yayasan Obor Indonesia, 2009), hal. 96
} 
Volume 2 Nomor 2, Desember 2019

E-ISSN : 2655-7347

dalam gejala yang bersangkutan. ${ }^{10)}$ Dalam penyusunan penulisan hukum yang berjudul “Analisis Terhadap Keterbukaan Informasi Publik Pada Perseroan Terbatas yang Melakukan Pengumpulan Dana Donasi untuk Pelaksanaan Corporate Social Responsibility, data-data mengenai jurnal ini diperoleh dengan cara-cara sebagai berikut:

\section{Jenis Penelitian}

Mengenai jenis penelitian, Mukti Fajar dan Yulianto Achmad membagi jenis penelitian ke dalam 2 (dua) bentuk, yakni penelitian hukum normatif dan penelitan hukum empiris (sosiologis). ${ }^{11)}$ Rony Hanitijo, mengemukakan pengertian dari kedua bentuk penelitian tersebut, bahwa:

"Penelitian hukum dapat dibedakan antara: Penelitian hukum normatif atau penelitian hukum doktrinal, yaitu penelitian hukum yang menggunakan sumber data sekunder atau data yang diperoleh melalaui bahan-bahan kepustakaan, dan penelitian hukum empiris atau penelitian hukum sosiologis, yaitu penelitian hukum yang memperoleh datanya dari data primer atau data yang diperoleh langsung dari masyarakat. ${ }^{12)}$

Dalam melakukan penelitian ini, penulis menggunakan jenis penelitian hukum normatif diengan maksud membuat suatu penelitian yang membahas mengenai keterbukaan informasi pada Perseoran Terbatas yang terdapat pada seluruh Undang-Undang yang berkaitan beserta penerapan prinsip CSR yang tertuang dalam UUPT berserta implikasi terhadap pelanggarannya.

\section{Sifat Penelitian}

Sifat Penelitian yang digunakan dalam penelitian ini adalah Deskriptif Analisis. Mukti Fajar dan Yulianto Achmad memberikan pengertian mengenai penelitian Deskriptif, bahwa peneliti dalam menganalisis berkeinginan untuk memberikan gambaran atau pemaparan atas subjek dan objek penelitian

10) Op. Cit, hal. 42-43

11) Ibid, hal.153

${ }^{12)}$ Ronny Hanitijo Soemitro, Metodologi Penelitian Hukum, (Jakarta: Ghalia Indonesia, 1983), hal. 24 
Volume 2 Nomor 2, Desember 2019

E-ISSN : 2655-7347

sebagaimana hasil penelitian yang dilakukannya. Di sini peneliti tidak melakukan justifikasi terhadap hasil penelitiannya tersebut. ${ }^{13)}$ Adapun penggunaan sifat Deskriptif Analisis dalam penelitian ini dikarenakan penulis melakukan pemaparan atas suatu Perseroan Terbatas yang dimasukan ke dalam kategori Badan Publik dan dalam kaitannya dengan keterbukaan informasi publik beserta implikasi pelanggaran CSR yang tertuang dalam UUPT dan implementasinya. Selain itu, penulis juga melakukan penggambaran atas suatu Badan Publik dan Perseoran Terbatas pada umumnya dan penerapan CSR yang terdapat di dalam undang-undang, sehingga diakhir penelitian ini kesenjangan dalam penerapan hukum terlihat, namun sesuai dengan definisi, penulis tidak melakukan justifikasi atas penelitian ini.

\section{Jenis Data}

Penggunaan Jenis data, terbagi atas 2 (dua) bentuk, yakni:

Data Primer dalam penelitian hukum adalah data yang diperoleh terutama dari hasil penelitian empiris, yaitu penelitian yang dilakukan langsung di dalam masyarakat, sedangkan Data Sekunder dalam penelitian hukum adalah data yang diperoleh dari hasil penelaahan kepustakaan atau penelaahan terhadap berbagai literatur atau bahan pustaka yang berkaitan dengan masalah atau materi penelitian yang sering disebut sebagai bahan hukum. ${ }^{14)}$ Mengenai bahan hukum, terbagi lagi ke dalam beberapa kelompok, yang diantaranya: ${ }^{15)}$

a. Bahan hukum Primer, yang terdiri atas peraturan perundang-undangan, yurisprudensi atau keputusan pengadilan (lebih-lebih bagi penelitian yang berupa studi kasus) dan perjanjian internasional. (traktat).;

b. Bahan hukum sekunder, yaitu bahan hukum yang dapat memberikan penjelasan terhadap bahan hukum primer, yang dapat berupa rancangan

\footnotetext{
13) Op. Cit, hal.183

14) Ibid, hal. 156

${ }^{15)}$ Ibid, hal. 157
} 
perundang-undangan, hasil penelitian, buku-buku teks, jurnal ilmiah, surat kabar (koran), pamphlet, lefleat, brosur, dan berita internet.;

c. Bahan hukum tersier, juga merupakan bahan hukum yang dapat menjelaskan baik bahan hukum primer maupun bahan hukum sekunder, yang berupa kamus, ensiklopedi, leksikon dan lain-lain.

Dalam penelitian ini, penulis menggunkan data primer berupa wawancara pihak-pihak yang terkait dalam kasus yang penulis angkat beserta beberapa ahli hukum dan data sekunder dengan bahan hukum primer dan bahan hukum sekunder, adapun penggunaan data beserta bahan hukum tersebut, dikarenakan penulis menggunakan peraturan peundang-undangan, buku-buku hukum, jurnal beserta berita. Sumber Penelitian yang Penulis gunakan ialah sumber hukum primer dan sumber hukum sekunder yang diantaranya adalah sebagai berikut:

a. Bahan Hukum Primer

1) Undang-Undang NRI Nomor 40 Tahun 2007 Tentang Perseroan Terbatas;

2) Undang-Undang NRI Nomor 14 Tahun 2008 Tentang Keterbukaan Informasi Publik;

3) Undang-Undang NRI Nomor 9 Tahun 1961 Tentang Pengumpulan Uang atau Barang;

4) Peraturan Pmerintah RI Nomor 29 Tahun 1980 Tentang Pelaksanaan Pengumpulan Sumbangan;

5) Peraturan Pemerintah RI Nomor 47 Tahun 2012 tentang Tanggung Jawab Sosial dan Lingkungan Perseroan Terbatas;

b. Bahan Hukum Sekunder

1) Buku-buku hukum yang relevan dengan kasus yang penulis angkat;

2) E-Jurnal;

3) Artikel-artikel hukum yang didapat di Intrenet. 
Volume 2 Nomor 2, Desember 2019

E-ISSN : 2655-7347

\section{Teknik Pengumpulan Data}

Mengenai Teknik Pengumpulan Data di dalam penelitian ini, penulis menggunakan cara studi kepustakaan untuk memperoleh bahan-bahan hukum primer beserta bahan hukum sekunder. Hal ini dikarenakan penulis menggunakan jenis penilitian hukum normatif. Namun tidak menutup kemungkinan bagi penulis untuk melakukan wawancara ke beberapa ahli dalam menemukan data yang hanya sebatas untuk memperkaya khasanah ilmu pengetahuan dalam jurnal ini.

\section{Teknik Pengolahan Data}

Dalam melakukan teknik pengolahan data, Mukti Fajar dan Yulianto Achmad memberikan gambaran yang sesuai dengan teknik yang penulis gunakan, bahwa dalam penelitian hukum normatif, pengolahan bahan berwujud kegiatan untuk mengadakan sistematisasi terhadap bahan-bahan hukum tertulis. Dalam hal ini pengolahan bahan dilakukan dengan cara, melakukan seleksi data sekunder atau bahan hukum, kemudian melakukan klarifikasi menurut penggolongan bahan hukum dan menyusun data hasil penelitian tersebut secara sistematis, dilakukan secara logis, artinya ada hubungan dan keterkaitan antara bahan hukum satu dengan bahan hukum lainnya untuk mendapatkan gambaran umum dari hasil penelitian. ${ }^{16)}$

Berdasarkan pendapat tersebut, penyeleksian terhadap seluruh bahan hukum yang penulis dapatkan merupakan cara dalam menulis jurnal ini, yakni melakukan seleksi terhadap bahan hukum yang relevan dengan permasahalan yang penulis angkat, yakni mengenai Keterbukaan Informasi Publik pada Perseroan Terbatas dan Badan Publik beserta pelaksaan CSR pada peraturan yang mengatur tentang kedua hal tersebut.

16) Ibid, hal. 181 
Volume 2 Nomor 2, Desember 2019

E-ISSN : 2655-7347

\section{Teknik Analisis Data}

Teknik analisis data pada permasalahan yang penulis angkat, penulis menggunakan sifat analisis secara deksriptif. Mukti Fajar dan Yulianto Achmad memberikan pengertian bahwa peneliti dalam menganalisis berkeinginan untuk memberikan gambaran atau pemaparan atas subjek dan objek penelitian sebagaimana hasil penelitian yang dilakukannya. ${ }^{17)}$ Penulis dalam melakukan penelitian melakukan beberapa pendekatan, yakni:

1) Pendekatan Perundang-Undangan yang didasarkan atas hirarki perundang-undangan;

2) Pendekatan Kasus, dimana penulis mendapati kasus yang terdapat dalam bahan hukum sekunder khususnya berita.

\section{PEMBAHASAN}

A. Pelaksanaan Corporate Social Responsibility Oleh Suatu Perseroan Terbatas Dan Informasi Publik Yang Tunduk Pada Ketentuan Undang-Undang NRI Nomor 14 Tahun 2008 Tentang Keterbukaan Informasi

Corporate Sosial Responsibility atau CSR pada pelaksanaannya di Indonesia dikenal pula dengan istilah Tanggung Jawab Sosial dan Lingkungan atau TJSL, UUPT dan beberapa Undang-Undang memberikan definisi mengenai CSR atau TJSL. Selain Undang-Undang, terdapat pula definisi mengenai TJSL yang dikemukakan oleh para ahli, Gunawan Widjaja dalam bukunya menyatakan bahwa TJSL atau Corporate Social Responsibility atau kadangkala disebut juga dengan Business Social Responsibility atau Corporate Citizenship pada prinsipnya merupakan bentuk kerjasama antara perusahaan (tidak hanya perseroan terbatas) dengan segala sesuatu atau segala hal (stakeholders) yang secara langsung maupun tidak langsung berinteraksi dengan perusahaan tersebut untuk tetap menjamin keberadaan dan

\footnotetext{
17) Ibid, hal. 183
} 
Volume 2 Nomor 2, Desember 2019

E-ISSN : 2655-7347

kelangsungan usaha (sustainability) perusahaan tersebut. ${ }^{18)}$ Dari definisi tersebut, dapat dikatakan bahwa TJSL atau CSR merupakan sebuah tanggungjawab perusahaan untuk melakukan hubungan dengan seluruh stakeholder dalam bentuk pembangunan demi melangsungkan kegiatan usaha.

Beberapa ahli berpendapat bahwa pelaksanaan CSR bertentangan dengan tujuan utama dari korporasi yakni mencari keuntungan. Mengutip pendapat Ian B. Lee dalam buku Mukhti Fajar menyatakan bahwa Korporasi didirikan oleh para pemegang saham untuk mencari keuntungan. ${ }^{19)}$ hal ini tentu saja bertentangan dengan konsep CSR yang dilakukan dengan menggunakan sebagian laba dari perusahaan untuk kepentingan stakeholder. Namun, terdapat pendapat lain yang menyatakan bahwa suatu korporasi dijalankan bukan semata-mata hanya mencari keuntungan, pendapat tersebut dikemukakan oleh Beth Stephens, yang mengatakan mencari keuntungan bukanlah satu-satunya tujuan perusahaan, namun hanya sebagai bisnis utamanya. Selebihnya korporasi harus memperhatikan kepentingan sosial dan lingkungan sebagai bagian dari tujuan perusahaan. ${ }^{20)}$

Salah satu pelaksanaan CSR yang secara umum dikenal adalah pemberian bantuan (donasi/charity), terhadap organisasi-organisasi lokal dan masyarakat miskin di sekitar korporasi beroperasi. Mengutip pendapat Philip Kotler dan Nancy Lee, setidaknya ada 6 (enam) pilihan sebagai motif korporasi melakukan CSR, yaitu: ${ }^{21)}$

\section{Causes Promotion}

Memberikan bantuan kepada masyarakat dalam bentuk sponsor sekaligus promosi.

\section{Causes Related Marketing}

18) Ibid, hal. 95-96.

19) Mukti Fajar ND, Tanggung Jawab Sosial Perusahaan di Indonesia: Studi tentang Penerapan Ketentuan CSR pada Perusahaan Multinasional, Swasta Nasional \& BUMN di Indonesia, (Jakarta: Pustaka Pelajar, 2013), hal. 43.

20) Ibid. hal. 96.

${ }^{21)}$ Ibid. hal 266 
Volume 2 Nomor 2, Desember 2019

E-ISSN : 2655-7347

Memberikan kontribusi atau donasi kepada masyarakat berdasarkan persoalan yang khusus menyangkut penggunaan dan penjualan produknya.

3. Corporate Social Marketing

Memberikan dukungan kepada masyarakat pada pengembangan atas perubahan perilaku sosial melalui kampanye, seperti cara hdup sehat, atau menciptakan lingkungan hidup yang nyaman.

\section{Corporate Philantrophy}

Memberikan sumbangan secara langsung (donation), tanpa dikaitkan dengan promosi atau kepentingan korporasi lainnya.

\section{Community Voluntering}

Memberikan dukungan dalam bentuk pendampingan untuk pemberdayaan masyarakat, seperti pelatihan keterampilan.

\section{Socially Reponsible Business Practices}

Memberikan dukungan dalam pengembangan yang disesuaikan dengan usaha atau kegiatan bisnis masyarakat.

Mengutip buku karangan Mukti Fajar, terdapat 4 (empat) teori hukum yang berkaitan dengan CSR, yang diantaranya adalah:22)

\section{Social Responsibility Theory}

Dikutip dari pendapat Peter Nobel dalam buku Mukti Fajar yang menyebutkan bahwa inti dari Social Responsibility Theory, adalah memberi kewajiban bagi direksi dan managemen korporasi untuk menjaga harmonisasi antara kepentingan shareholder dan stakeholder.

\section{Hobbesian Leviathan Theory}

Dalam teori ini, menghendaki adanya control yang ketat dari pemerintah, serta meniadakan upaya-upaya lainya. Thomas Hobbes dalam leviathan mengajarkan bahwa control rutin oleh pemerintah sangat efektif dalam penegakkan hukum.

\footnotetext{
${ }^{22)}$ Ibid. hal. 29.
} 
Volume 2 Nomor 2, Desember 2019

E-ISSN : 2655-7347

\section{Corporate Governance Theory}

Menghendaki adanya Corporate Accountability dari direksi korporasi. Akuntabilitas ini ditujukan untuk pertanggungjawaban langsung terhadap pemegang saham sesuai dengan hukum perusahaan.

\section{Reflexive Law Theory}

Mukhti fajar dalam bukunya menyatakan bahwa teori ini digunakan untuk mengatasi kebuntuan atas pendekatan formal terhadap kewajiban perusahaan dalam sistem hukum. Lebih lanjut David Hess memberikan pendapat bahwa reflexive law theory adalah teori hukum yang menjelaskan adanya keterbatasan hukum (limit of law) dalam masyarakat yang komplek untuk mengarahkan perubahan sosial secara efektif. ${ }^{23)}$

Dalam hal ini, penulis cenderung menggunakan reflexive law theory dalam penulisan ini, dikarenakan terdapat keterbatasan hukum mengenai penerapan sanksi yang terdapat dalam berbagai perangkat hukum di Indonesia, sehingga penulis hendak menemukan letak keterbatasan tersebut dan akibat hukum yang akan ditimbulkan. Selain itu, beranjak dari duduk perkara sebagaimana yang telah penulis paparkan pada bagian latar belakang, penulis sependapat dengan pendapat David Hees sebagaimana dikutip dari buku Mukti Fajar, dimana untuk mengkaji CSR, reflexive law theory adalah teori hukum yang berupaya mendorong korporasi untuk menilai kembali praktek-praktek yang telah mereka lakukan dengan memberikan informasi yang mutakhir. Dalam mengontrol perilaku korporasi, reflexive law theory menghendaki adanya social accounting, auditing, dan reporting yang disebut social reporting. Laporan sosial adalah bentuk laporan singkat mengenai dampak sosial dari perilaku korporasi secara etika terhadap kepentingan masyrakat atau stakeholders. ${ }^{24)}$ Lebih lanjut dalam banyak hal, laporan sosial adalah sama dengan audit keuangan perusahaan,

23) David Hess, Social Reporting: A Reflexive Law Approach to Corporate Social Responsiveness, (Journal of Corporation Law 25, Fall: 2000), hal. 42.

${ }^{24)}$ Dr. Mukti Fajar ND, Op. Cit., hal.32. 
Volume 2 Nomor 2, Desember 2019

E-ISSN : 2655-7347

tetapi yang berkaitan dengan penampilan sosial (social performance) dari korporasi. ${ }^{25}$ Sehingga terdapat korelasi antara permasalahan yang penulis angkat dengan penerapan teori ini sebagai dasar pijakan penelitian.

Beranjak dari ketentuan CSR atau TJSL yang terdapat di dalam UUPT, dapat dikatakan bahwa pelaksanaan CSR atau TJSL, merupakan kewajiban bagi suatu perseroan terbatas. Mengutip beberapa pendapat ahli yang telah dipaparkan sebelumnya bahwa awal mulanya CSR atau TJSL merupakan hal yang sifatnya tidak wajib, bahkan bertentangan dengan prinsip utama suatu konsep perusahaan yakni mencari keuntungan karena pelaksanaan CSR atau TJSL menggunakan sebagian keuntungan atau laba yang didapat oleh perusahaan. Pada dewasa ini, terdapat pendapat lain yang menyatakan bahwa CSR atau TJSL merupakan suatu kewajiban dalam arti kewajiban moral untuk membangun ekosistem perusahaan yang baik dengan masyarakat sekitar. Hal ini juga dimaksudkan agar perusahaan tetap eksis di mata masyarakat dengan melakukan berbagai macam kegiatan yang sifatnya membangun taraf kehidupan yang layak bagi masyarakat di lingkungan sekitar perusahaan.

Adanya perintah dari Undang-Undang tentang kewajiban perusahaan untuk melaksanakan CSR atau TJSL, maka pendapat yang menyatakan bahwa pelaksanaan CSR atau TJSL tidak bersifat wajib bagi suatu perusahaan tentunya tergeser dengan pendapat yang menyatakan bahwa CSR atau TJSL bersifat mandatori atau wajib bagi perusahaan agar perusahaan tersebut dapat terus membangun hubungan yang baik dengan masyarakat. Konsep filanropi menjadi motif dibalik suatu perusahaan menjalankan pengumpulan dana donasi yang kemudian diberikan langsung atau tidak langsung kepada masyarakat.

Peraturan Pemerintah Nomor 47 Tahun 2012 Tentang Tanggung Jawab Sosial dan Lingkungan Perseroan Terbatas, sebagai salah satu aturan yang mengakomodir pelaksanaan CSR atau TJSL, dimana dalam peraturan tersebut memuat ketentuan penyusunan rencana pelaksanaan CSR atau TJSL yang

\footnotetext{
25) Ibid.
} 
Volume 2 Nomor 2, Desember 2019

E-ISSN : 2655-7347

dimuat di dalam rencana kerja tahunan perseoran terbatas oleh direksi, pelaporan yang termuat di dalam laporan tahunan yang dipertanggungjawabkan kepada RUPS serta sanksi bagi perseroan terbatas yang tidak melaksanakan CSR atau TJSL, dimana sanksi tersebut diatur pula pada peraturan yang lain. Pada peraturan tersebut, terdapat kewajiban untuk memberikan laporan pelaksanaan CSR atau TJSL kepada publik, namun pada prakteknya, pelaksanaan CSR atau TJSL, biasanya dimuat di dalam surat kabar atau bahkan laporan keuangan yang dapat diakses melalui internet seperti halnya yang dilakukan oleh PT. Sumber Alfaria Trijaya. Hal tersebut dapat dikatakan sebagai suatu pencapaian yang dilakukan oleh perseroan karena telah melakukan pembangunan berkelanjutan bagi masyarakat sekitar dan dapat pula dilakukan sebagai motif untuk melakukan promosi terhadap perusahaan tersebut.

Tidak ada kewajiban untuk melakukan pelaporan kepada publik mengenai pelaksanaan CSR atau TJSL dapat didasarkan pada anggaran yang digunakan untuk pelaksanaan CSR atau TJSL, dimana pelaksanaannya menggunakan dana perusahaan atau laba perusahaan, sehingga perusahaan hanya berkewajiban untuk melakukan pelaporan kepada RUPS sesuai dengan peraturan perundangundangan yang berlaku. Mengenai pemublikasian CSR atau TJSL yang telah dilakukan oleh suatu perseroan terbatas sebagai suatu pencapaian, dikembalikan kepada keinginan perusahaan untuk mempublikasikan kepada publik atau tidak karena tidak ada aturan tertulis mengenai kewajiban untuk melakukan publikasi kepada publik terkait dengan pelaksanaan CSR atau TJSL.

Mengingat kembali pengertian informasi publik pada UU KIP, bahwa informasi publik berkaitan dengan pelaksanaan kegiataan penyelenggaraan negara yang dilakukan oleh badan publik. Badan publik tersebut diantaranya adalah badan legislatif, eksekutif, dan yudikatif serta badan publik lain yang melakukan kegiatan penyelenggaraan negara, dimana sebagian atau seluruh sumber dananya berasal dari APBN dan/atau APDB, sumbangan masyarakat 
Volume 2 Nomor 2, Desember 2019

E-ISSN : 2655-7347

dan/atau luar negeri. Lahirnya undang-undang ini menjadikan publik dapat ikut memantau kegiatan yang dilakukan oleh badan publik dalam rangka melakukan kegiatan penyelenggaraan negara agar tidak ada yang disalahgunakan, mengingat sumber dana yang didapat oleh badan publik sebagaimana yang dimaksud dalam Pasal 1 ayat (3) Undang-Undang Nomor 14 Tahun 2008 Tentang Keterbukaan Informasi Publik.

Hal yang perlu dicermati adalah memang laporan CSR atau TJSL bukan merupakan laporan yang diwajibkan oleh UU KIP, karena kegiatan CSR atau TJSL merupakan kegiatan yang tunduk pelaksanaannya di bawah peraturan perundang-undangan yang lain. Namun apabila mencermati kasus yang penulis angkat, dana yang dikumpulkan oleh PT. Sumber Alfaria Trijaya Tbk, merupakan dana donasi yang dikumpulkan oleh masyarakat namun laporan yang pelaksanaan penyaluran dana donasi tersebut yang disatukan dengan laporan CSR atau TJSL, sehingga menimbulkan kekaburan bagi masyarakat publik dalam membaca keuda laporan tersebut.

Pada kasus yang melibatkan Mustolih sebagai pihak pemohon Keterbukaan Informasi atas dasar pengumpulan dana donasi yang dilakukan oleh PT. Sumber Alfaria Trijaya dan dilaporkan oleh perseroan tersebut sebagai bentuk pelaksanaan CSR, menimbulkan pertentangan pada pengertian badan publik yang terdapat di dalam UU KIP. Sebagai Perseroan Terbatas yang tunduk pada UUPT dan memiliki beberapa informasi mengenai perseroan yang terbatas bagi pihak yang berkepentingan dalam perseroan terbatas, tentunya masuk PT. Sumber Alfaria Trijaya Tbk, sebagai badan publik di satu sisi akan menimbulkan polemik bagi perusahaan atau perseroan terbatas lain yang hendak melakukan filantropi atau melakukan pemberian dana sumbangan yang berasal dari perusahaan. Di sisi lain, PT. Sumber Alfaria Trijaya yang telah mengantongi izin dari Kementerian Sosial berdasarkan surat keputusan Menteri Sosial Nomor 22/HUK-PS/2016 dan surat keputusan Menteri sosial Nomor 900/HUK-PS/2015 serta melakukan publikasi yang dapat diakses dari website 
Volume 2 Nomor 2, Desember 2019

E-ISSN : 2655-7347

Alfamart sendiri, sehingga dalam hal ini informasi yang dimintakan oleh Mustolih sejatinya telah ada dan terdapat kebebasan bagi Mustolih atau pihak lain untuk mengakses di website tersebut walau informasi tersebut terbatas pada dana yang telah terkumpul dan pihak-pihak yayasan yang disalurkan dananya oleh PT. Sumber Alfaria Trijaya.

CSR atau TJSL yang dilaksakan dengan menggunakan dana atau laba perusahaan, tentunya bukan lah informasi publik yang tunduk pada UU KIP. Namun, dengan adanya putusan hakim yang menyatakan bahwa PT. Sumber Alfaria Trijaya Tbk telah melakukan kegiatan pengumpulan dana sumbangan yang dimana dana tersebut bersumber dari masyarakat, maka dalam hal ini, PT. Sumber Alfaria Trijaya Tbk masuk ke dalam kategori badan publik dan mewajibkan PT. Sumber Alfaria Trijaya Tbk untuk memberikan informasi kepada Mustolih terkait dengan penggunaan dana donasi tersebut serta dokumen-dokumen lain yang berkaitan dengan izin dan penyelenggaraan pengumpulan dana donasi. Hal tersebut merupakan amanat dari UU KIP, dimana PT. Sumber Alfaria Trijaya yang masuk ke dalam kategori organisasi nonpemerintah untuk membuka informasi penggunaan dana yang bersumber dari masyarakat.

Sesuai dengan pendapat ahli pada bab sebelumnya, bahwa dikategorikannya PT. Sumber Alfaria Trijaya Tbk, sebagai badan publik pada sengketa ini, tidak menjadikan perseroan tersebut sepenuhnya menjadi badan publik yang tunduk pada Undang-Undang Nomor 14 Tahun 2008 Tentang Keterbukaan Informasi Publik. Alasan utama PT. Sumber Alfaria Trijaya Tbk, masuk ke dalam kategori badan publik adalah karena mengelola dana donasi yang informasinya harus transparan, baik dipertangungjawabkan kepada kementerian sosial sebagai badan yang memberikan izin dan juga kepada masyarakat sebagaimana yang dimaksud dalam Undang-Undang. Informasi mengenai pengumpulan dana donasi tersebut juga sejatinya mudah diakses dan diketahui oleh masyarakat, agar masyarakat bisa memantau penggunaan dana 
Volume 2 Nomor 2, Desember 2019

E-ISSN : 2655-7347

donasi tesebut sebagaimana mestinya dan tidak menimbulkan kecurigaan bahkan terjadi penggelapan terhadap dana donasi tersebut.

B. Akibat hukum terhadap suatu badan publik yang tidak menjalankan keterbukaan informasi sesuai dengan Undang-Undang NRI Nomor 14 Tahun 2008 Tentang Keterbukaan Informasi Publik

Informasi Publik merupakan hal yang diatur di dalam ketentuan UU KIP. Informasi Publik ini diperuntukkan bagi setiap badan publik yang tunduk pada UU KIP ini pada pasal 1 ayat (2) UU KIP. Dalam hal ini, bagi setiap badan publik yang masuk ke dalam kategori yang ditentukan oleh UU KIP, maka terdapat kewajiban untuk memberikan Informasi bagi pemohonnya. Sebagaimana yang terdapat di dalam pasal 7 ayat (1) UU KIP.

Sesuai dengan Undang-Undang tersebut, setiap badan publik diwajibkan untuk memberikan informasi kepada publik sesuai dengan jangka waktu informasi publik tersebut. Informasi publik tersebut meliputi informasi yang wajib disediakan dan diumumkan secara berkala, informasi yang wajib diumumkan secara serta-merta dan informasi yang wajib tersedia setiap saat. Ditetapkannya PT. Sumber Alfaria Trijaya Tbk, sebagai badan publik sehingga mewajibkan perseroan tersebut untuk memberikan laporan pengumpulan dana donasi yang kemudian disalurkan kepada beberapa yayasan di Indonesia. Melihat beberapa jenis informasi yang wajib disediakan menurut UU KIP, pelaksanaan pengumpulan dana donasi yang dilakukan oleh PT. Sumber Alfaria Trijaya Tbk, wajib disediakan secara berkala, dikarenakan hal tersebut berkaitan dengan kegiatan badan publik, sehingga harus tersedia dan dapat diakses oleh masyarakat.

Kembali beranjak dari penetapan PT. Sumber Alfaria Trijaya Tbk, sebagai badan publik yang menimbulkan perdebatan serta pihak PT. Sumber Alfaria Trijaya Tbk yang hingga sekarang menolak untuk ditetapkan sebagai badan publik, maka menimbulkan ketidakwajiban pula bagi PT. Sumber Alfaria Trijaya Tbk, untuk memberikan informasi terkait dengan pelaksanaan 
Volume 2 Nomor 2, Desember 2019

E-ISSN : 2655-7347

pengumpulan dana donasi yang dikumpulkan dari masyarakat. Walau tidak terdapat pernyataan dari PT. Sumber Alfaria Trijaya yang menyatakan untuk menolak memberikan informasi tersebut, namun Undang-Undang Nomor 14 Tahun 2008 Tentang Keterbukaan Informasi Publik memberikan sanksi bagi badan publik yang tidak memberikan informasi yang dimaksudkan dalam undang-undang tersebut, yakni penggunaan sanksi pidana kurungan dan sanksi denda.

Pada Pasal 52 yang menyatakan bagi badan publik yang dengan sengaja tidak memberikan informasi yang dimaksud dalam Undang-Undang tersebut dan menimbulkan kerugian bagi pihak lain, maka dapat dipidana kurungan paling lama 1 (satu) tahun dan/atau denda sebanyak 5 (lima) juta rupiah. Berdasarkan rumusan pasal tersebut, maka menimbulkan konsekuensi bahwa kerugian yang diderita oleh para pihak haruslah dibuktikan apabila terdapat pihak yang merasa dirugikan atas tidak diberikannya informasi publik yang terkait. Menurut pejabat terkait dalam Komisi Informasi Publik, adanya unsur kerugian yang ditimbulkan dikarenakan menolaknya suatu badan publik untuk memberikan informasi dibuktikan oleh pihak kepolisian dengan membuat laporan. Majelis hakim dalam komisi infomasi publik, tidak memberikan putusan yang sifatnya menjatuhkan sanksi berupa kurungan dan denda atas kesengajaan pihak termohon yang tidak memberikan informasi kepada publik dan menimbulkan kerugian. Adapun kewenangan untuk menjatuhkan sanksi pidana kurungan dan denda tersebut, diberikan kepada Pengadilan Negeri sesuai dengan domisili.

Beranjak pada kasus ini, setiap konsumen yang berbelanja di Alfamart dimintakan secara sukarela untuk melakukan sumbangan dan jumlah sumbangan yang dimintakan tidak lebih dari Rp400,00 (empat ratus rupiah). Kedudukan pihak pemohon atau Legal Standing haruslah jelas apabila pihak pemohon informasi tersebut merasa dirugikan akibat dari penolakan pihak badan publik yang menolak untuk membuka informasi sebagaimana yang 
Volume 2 Nomor 2, Desember 2019

E-ISSN : 2655-7347

termaksud di dalam Undang-Undang NRI Nomor 14 Tahun 2008 Tentang Keterbukaan Informasi Publik. Undang-Undang tersebut memang menyatakan bahwa setiap orang dapat menjadi pemohon dalam sengketa informasi publik, namun dalam hal ini komisi informasi publik hanya akan menjatuhkan putusan yang bersifat memerintah pihak termohon untuk memberikan informasiinformasi yang dimintakan oleh pemohon, kemudian pemohon bisa meminta pengajuan eksekusi putusan pada pengadilan negeri setempat apabila terdapat unsur kerugian, maka pemohon dapat membuat laporan pada pihak kepolisian agar pihak kepolisian dapat melakukan pemeriksaan terkait adanya kerugian yang ditimbulkan. Pemeriksaan secara mendalam tetap dilakukan oleh majelis hakim atau pejabat yang berwenang dalam agar sanksi yang diapat dijatuhkan kepada badan publik yang menolak untuk memberikan informasi terkait

Pada laporan keuangan yang diterbitkan oleh PT. Sumber Alfaria Trijaya Tbk, dana donasi yang terkumpul mencapai kurang lebih 33 (tiga puluh tiga) miliyar. Pelaporan informasi penggunaan dana tersebut menjadi penting, dikarenakan jumlahnya yang cukup banyak dan melibatkan banyak pihak khususnya konsumen yang dimintakan uang kembalian belanjanya secara sukarela oleh pihak kasir untuk didonasikan. Memang sejatinya undang-undang telah memberikan ketentuan dengan jelas mengenai sanksi bagi badan publik yang tidak memberikan informasi sebagaimana yang terdapat dalam undangundang Nomor 14 Tahun 2008 Tentang Keterbukaan Informasi Publik, namun dalam hal kasus ini, Majelis Hakim pada sengketa informasi publik tidak memberikan sanksi apapun bagi pihak PT. Sumber Alfaria Trijaya Tbk, yang dalam hal ini menolak untuk dimasukan ke dalam kategori badan publik sebagaimana yang dimaksud dalam Undang-Undang Nomor 14 Tahun 2008 Tentang Keterbukaan Informasi Publik.

Adapun pihak badan publik dapat mengajukan keberatan untuk membuka informasi yang dimintakan oleh pemohon dengan mengemukakan alasannya. Pada kasus ini, alasan utama PT. Sumber Alfaria Trijaya Tbk, adalah tidak 
Volume 2 Nomor 2, Desember 2019

E-ISSN : 2655-7347

termasuknya PT. Sumber Alfaria Trijaya Tbk, sebagai badan publik, selain itu, perusahaan tersebut juga telah memberikan publikasi terkait dengan penggunaan dana donasi tersebut yang langsung disalurkan kepada beberapa yayasan terkemuka di Indonesia.

\section{PENUTUP}

\section{A. Kesimpulan}

1. CSR merupakan suatu bentuk kegiatan yang dilakukan oleh suatu perseroan dengan tujuan untuk menjaga keberlangsungan kegiatan perusahaan dengan memberikan suatu pembangunan berkelanjutan baik itu pada bidang Pendidikan, lingkungan maupun sosial. Hal tersebut dimaksudkan juga untuk menjaga hubungan dengan pemangku kepentingan, salah satunya masyarakat. CSR yang merupakan suatu bentuk kewajiban, meliputi juga kewajiban untuk memberikan laporan mengenai kegiatan tersebut, namun hanya sebatas pada investor ataupun pihak-pihak yang terlibat dalam perusahaan tersebut yang tertuang dalam laporan keuangan perseroan. Pemublikasian kepada masyarakat mengenai kegiatan CSR bukanlah suatu kewajiban dikarenakan tidak diatur pada undang-undang, baik itu UUPT atau UU KIP, sehingga dapat dikatakan pula informasi mengenai CSR bukanlah informasi publik sebagaimana yang dimaksud dalam UU KIP. Pada kasus yang melibatkan PT SAT dengan Mustolih Siradj ini, akan menjadi masalah apabila PT SAT menyatakan bahwa dana donasi yang telah dikumpulkan dan disalurkan ke berbagai yayasan merupakan bentuk kegiatan CSR yang dilakukan oleh PT SAT, dikarenakan terang bahwa UUPT menyatakan apabila CSR dilakukan menggunakan laba perusahaan. Penetapan badan publik pada perseroan terbatas juga akan menimbulkan masalah jika tidak 
dibatasi secara jelas khususnya mengenai perseroan terbatas yang melakukan kegiatan serupa, dikarenakan kembali pada maksud didikannya suatu perseroan terbatas, yakni mencari keuntungan.

2. Akibat hukum bagi suatu badan publik yang menolak untuk memberikan informasi sebagaimana yang dinyatakan oleh UU KIP, maka terdapat sanksi pidana serta sanksi administrasi. Salah satu frasa yang terdapat dalam UU KIP yang mengatur mengenai sanksi pidana menyatakan bahwa menimbulkan kerugian atas tidak diberikannya informasi publik tersebut, Sehingga harus terdapat kerugian yang diderita bagi pihak yang tidak mendapatkan informasi tersebut. Berkaitan dengan kasus yang penulis angkat, sanksi yang diberikan kepada PT SAT, hanyalah sanksi administrasi berupa teguran dan kewajiban bagi PT SAT untuk memberikan informasi mengenai pengumpulan dana donasi yang dimintakan oleh Bapak Mustolih Siradj.

\section{B. Saran}

1. Bagi pemerintah berupa Kemensos, agar memberikan penyeleksian dan pengawasan terhadap suatu perseroan yang hendak melakukan pengumpulan dana donasi. Penyeleksian dimaksudkan agar perseroan memiliki kegiatan yang jelas dan dapat dipertanggungjawabkan sedangkan pengawasan dimasudkan agar kegiatan yang dilakukan atas dasar filantropi dapat berjalan dengan maksimal tanpa adanya kekhawatiran penggelapan uang atau penyalahgunaan lainnya. Selain itu, pemerintah dalam hal ini membuat suatu standar pelaporan keuangan untuk perseroan terbatas yang memiliki kegiatan yang berhubungan dengan masyarakat, sehingga kasus seperti PT SAT yang menimbulkan ketidakpahaman masyarakat dapat diminimlisir. Begitu pula bagi perseroan terbatas, agar tidak ragu untuk memberikan informasi 
Volume 2 Nomor 2, Desember 2019

E-ISSN : 2655-7347

yang berkaitan dengan dana masyarakat dan memaksimalkan pemublikasian mengenai informasi yang wajib diberikan, tidak hanya serta merta melakukan publikasi namun keterjangkauan informasi tersebut masih sulit didapatkan oleh masyarakat.

2. Memaksimalkan sanksi yang diamanatkan oleh UU KIP, tidak hanya sanksi administrasi saja, namun pencabutan izin pengumpulan uang dan barang, bagi suatu organisasi yang tidak memberikan informasi dan laporan pertanggunjawaban atas kegiatannya. Bagi Komisi Informasi Publik kedepannya hanya tidak menjadi sarana ajudikasi, namun dapat menjadi wadah bagi masyarakat yang tidak paham mengenai informasi yang wajib diberikan oleh suatu entitas.

\section{DAFTAR PUSTAKA}

\section{A. Buku}

Fajar, Mukti ND. Tanggung Jawab Sosial Perusahaan di Indonesia: Studi tentang Penerapan Ketentuan CSR pada Perusahaan Multinasional, Swasta Nasional \& BUMN di Indonesia. (Jakarta: Pustaka Pelajar. 2013.)

Hanitijo, Ronny Soemitro. Metodologi Penelitian Hukum. (Jakarta: Ghalia Indonesia, 1983.)

Irianto, Sulistyowati dan Shidarta. Metode Penelitian Hukum: Konstelasi dan Refleksi”. (Jakarta: Yayasan Obor Indonesia, 2009.)

Mahmud, Peter Marzuki. Penelitian Hukum: Edisi Revisi. (Surabaya: Kencana, 2005.)

Rahardjo, Satjipto. Hukum dalam Perspektif Sejarah dan Perubahan Sosial dalam Pembangunan Hukum dalam Perspektif Politik Hukum Nasional. (Jakarta: Rajawali Press, 1996.)

Soehino. Ilmu Negara Liberty. (Yogyakarta: 1980) 
Volume 2 Nomor 2, Desember 2019

E-ISSN : 2655-7347

Soejono, Kejahatan dan Penegakan Hukum di Indonesia. (Jakarta: Rineka Cipta, 1996.)

Soekanto, Soerjono. Pengantar Penelitian Hukum. (Jakarta: UI Press. 1986.)

\section{B. Artikel Jurnal Cetak}

Hess, David. Social Reporting: A Reflexive Law Approach to Corporate Social Responsiveness. Journal of Corporation Law 25: Fall, 2000.

\section{Website}

Eben, Raja Lumbanrau. "Putusan KIP: Alfamart Gunakan Donasi Untuk CSR Perusahaan”. www.cnnindonesia.com. CNN Indonesia diakses pada 6 Februari 2019. 